DOI https://doi.org/10.18551/rjoas.2017-06.17

\title{
DIAGNOSIS OF MIDDLE MANAGER'S INDIVIDUAL WORKING BEHAVIOR IN TURNOVER INTENTION TRANSITION PHASE
}

\author{
Putranti Honorata Ratnawati Dwi ${ }^{*}$, Tiyoso Jaluanto Sunu Punjul \\ Faculty of Economic and Business, \\ 17 Agustus 1945 Semarang University, Indonesia \\ *E-mail: ratna.permai@gmail.com
}

\begin{abstract}
The aim of this research was focused on voluntary turnover with the cause of pull factor's concept. This research is also aimed to set a recommendation in order to reduce the garment industry employee's turnover rates. This research discussed the pull factors of an employee to stay at a company after having a turnover intention. Process between employee's turnover intention and turnover which ends with the decision to leave or stay with the company is an important factor to be understood so that the company could give an appropriate policy. Employee who leaves the company will cause physical and psychological loss. This research used qualitative research method by deeply interviewing six supervisors as the key informant, a chief, and an HRD manager to complete the information and data triangulation. The research object was a garment company in Klari Sub District, Karawang, and West Java, Indonesia. Research results showed that the cause of turnover intention from the individual perspective consists of implementation success, responsibility, recognition, development, the work itself, and stress. Employee had a choice, after turnover intention came, it may become real turnover or not. Actually, there is a process in the transition time that makes a turnover could not happen suddenly.
\end{abstract}

\section{KEY WORDS}

Turnover intention, individual behavior, employee's pull factor, manager, voluntary turnover, garment industry.

Turnover problem involves psychological and physical aspects, which are not easily understood. Physical aspects can be easily felt or seen, for example, an employee cannot achieve a higher productivity level, decreasing contribution to the company, had a work accident, or cannot use the production tools effectively (Abbasi, 2008; Chawla and Sondhi, 2011; Jha, 2012; Yin-Fah, 2010). By the signs that could be seen, physical problems were easy to overcome by the company's policy. Turnovers that leads to psychological impacts are more difficult to be understood. For example, there is a satisfaction factor as the main reason of an employee to leave the company (Mobley et al., 1978; Mobley, 1982). This is because the measurement of satisfaction is different for every individual.

Employee turnover has an important implication for the individual who leaves the job. There is a significant energy that should be taken out to find a new job, and to adapt to a new situation. Besides that, adaptation and relationship to the abandoned group will cause a stress (Boswell et al, 2005). Therefore, employee turnover topic is clearly relevant to a manager, researcher, and individual (Zedeckand Mosier, 1990). Besides physical and psychological problems, high turnover is also viewed as the cause of low competitiveness (Bax, 2000; Palupi, 2011).

Employee turnover always is a dynamic field on the developmental research despite many academic studies already discussed the topic. There is strategic research on human resource that investigates the mechanism between human-resource practice and company performance (Collins and Clark, 2003; Hatch and Dyer, 2004). Variable related to working (such as role conflict and work partner support), environmental factor (such as the possibility of getting a job), and employee orientation (such as organizational commitment or turnover intention) (Iverson and Marguere, 2000). 
It researches about voluntary turnover began in 1980 until 1995 (Holtom et al, 2008). This research offers a voluntary turnover model which is not only sought as the cause of turnover but also the process after turnover intention. Nevertheless, this model is not yet tested empirically. An empirical study stated that if someone leaves the organization, he will get involved to behavioral distortion and reduce the effort towards better performance (Sandep and Manjari, 2010). One of the factors that affect turnover is turnover intention (Jha, 2012; Kim, 2012). If the organization can predict the employee who has a turnover intention, management can determine the possibility of them leaving the organization. This will help the organization to reduce overall turnover and help the manager to make a suitable company policy for the employee who has turnover intention.

According to the problems stated before, clearly there is lacked of information in research on the effect of turnover intention. This research will offer a factor model as the pull of garment industry supervisors after having a turnover intention. This research will also study the effects to the individual, group, and the company.

The aim of this research was focused on voluntary turnover with the cause of pull factor's concept. This research is also aimed to set a recommendation in order to reduce the garment industry employee's turnover rates.

\section{LITERATURE REVIEW}

The Relationship of Turnover and Turnover Intention. The relationship between real turnover and turnover intention was stated by Henberger and Saosa-Poza (2004). In their research, turnover intention was $93,43 \%$ and among them only $6,57 \%$ that are realized into leaving the company. From that result, it can be interpreted that not every employee who has turnover intention will realize it into leaving the company. It takes different time in different individuals. Most studies focused on the turnover of an employee who had left the organization. The studies of turnover intention are mostly directed at the cause of turnover (Alkahtani, 2015; Lee and Huang, 2015; Saeed et al., 2014; Kim, 2012). Although the attention towards turnover intention keeps increasing and explains more about the cause of turnover, study that aimed to understand and explain the employee's behavior after the rise of turnover intention until the period of turnover is still rare to find (Johnston and Naiman, 1990).

Researchers had already shown that the order to a turnover process is from the cognition process to stop working, intention to seek a new job and intention to quit (Mobley et al., 1978; Mobley, 1982). Chandrasekhara (2000) gives a model which stated if affective commitment as the impact of sustainable organizational commitment is low, then it will affect the uncertainty of willing to quit the organization or stay. This will cause the intention and possibility to quit. The employee who quits from the company has many reasons to quit. The reason is not only because of unfavorable condition such as low satisfaction or changing commitment to the company, but also because of factors that indicate arising barriers such as work chances, unexpected offerings, or career aspirations (Lee and Mitchell, 1994; Maertz and Campion, 2004; Mobley, 1978).

It most researches focused on "push" model that caused the real turnover and the conceptualization of turnover behavior according to the attitude towards current job (Lee and Mitchell, 1994). A model from Ertmer and Newby (1993) was stated from the research on nurse's turnover intention. There are some variables that could be considered by a company to hold the employee before they make the real turnovers. This research stated that real turnover could be divided into some types, like based upon the length of employee's work. A new employee will be stressed by adaptation or in the locus of control, so he may decide to leave the company. However, there is still no researches that investigate what are the variables affecting the decision.

The research of Maertz and Campion (2004) gave a systematical explanation related with the type of turnover decision (impulsive, comparative, planned, and conditional quit), so that each group is having different motivation. They identified eight causes of turnover's proximal cognitions. The research of Krishnan and Singh (2010) explained that an employee 
who has turnover intention will show organizational deviance (OD) behavior, organizational citizenship behaviors (OCB), and performance orientation (PO) as moderator variables. It researches about turnover intention are mostly done to the employee who has high education and position (Blommea, 2010; Chawla, 2011; Kim, 2012). Research in higher job position is considered more meaningful than in lower employee level. However, researches of Palupi (2011), Mbah and Ikemefuna (2012), Yuccell (2012), and Yin-Fah (2010) stated that employee with lower educational experience and lower job positions (supervisor, middle manager, household assistant, and factory workers) and laborers also have turnover intention. Research by Kim (2012) stated that gender and work were affecting turnover intention.

Middle employees are also needed to be concerned with the intention to leave the organization because in this level, the problem is much bigger (Mowday et al., 1984). Middle manager or administration manager, including division Manager is responsible for the implementation of the operational plan which set by the top manager. This is same with the employee in supervisor position (middle manager) of garment (textile) industry. If the middle manager left the organization, that will cause loss of time, knowledge, and disturb the production target.

This research was done in garment industry called Textile and Textile Product (TPT) in Klari Sub District, Karawang Regency, and East Java. As one of the industries that were long developed in Indonesia, TPT industry holds an important role in economic structure. Textile industry is actually included into high creation density industry with high contribution to the Gross Domestic Income (GDI) according to Wike (2014). Turnover level of the employee in this industry is always increasing each year. According to survey data by Tower Watson (2014), industrial company commonly has a high turnover rate.

Turnover Intention and Its Process. Employee turnover or the in and out of an employee within an organization is important phenomena. Before a turnover, an employee has a willing or intention to leave the company. Turnover intention (the willing to move) can lead directly to real turnover. Turnover is described by Price (1992) as the movement of individual to pass the limit of membership in a social system. According to this research, turnover is a dynamic process when an employee leaves the organization. Individual is no longer receiving money or something equal to the organization from which they stay.

Herbert Simon in Gudono (2014) is not fully agreed to the rationality concept. He proposes a theory called normative bounded rationality, which stated that human can be failed to be fully rational because of some factors such as: (1) limited ability to process information, (2) the use of judgmental heuristic, and (3) in complex situation people cannot maximize the objective but merely get into the satisfying objective. Heuristic is a role of thumb, a simple way in which someone processes the information simply in the brain. There is two way of heuristic: (1) tendency to be based upon available information in memory (availability heuristic) and (2) tendency to judge something based on what they know (representativeness heuristic).

The result from this process of evaluation is that employee will decide to leave or stay. The final step of this alternative process is the decision to leave the current position. According to this model, decision to leave the position is the discussable process. Impulsive behavior is in the form of thought of quit, but it is not always thought about (Mobley, 1977).

\section{METHODS OF RESEARCH}

This research used qualitative method in collecting data. The researcher aimed to understand the social situation deeply, find a pattern, hypothesis, and a theory (Sugiyono, 2008). This research was done in a garment factory in Klari, Karawang. Interview had been done openly. Informants had been chosen purposively based upon the mastery over the problem. The informants were supervisors of garment industry in Klari Karawang. Informants and key informants in this research were: supervisor of garment industry, chief, HRD manager, and employee (supervisor) with turnover intention. Informant was chosen with snowball sampling technique. Employee with turnover intention was known through deep 
observation and interview with chief and HRD manager. The suggestions from an interview will be helping to choose the key informants. This is important so that the key informants can give the information openly. As we know, people tend not to tell bad thing about themselves. Interviews were done outside the working hour in order to make the data natural and not disturbing the work because each interview needs an hour. Data was analyzed by triangulation and comparison to other sources (chief, other supervisors, and HRD manager). There are six supervisors as an informant. Supervisor 1, 2, and 3 are supervisors who are still staying with the company, meanwhile supervisor 4,5 , and 6 are supervisors who are used to work in the position and currently left the company. There is a company's chief, and a HRD manager. Two-faced interview was done in order to get enough information and data triangulation. The research was done in 2014-2015.

According to the introduction, the model plan as this research's base could be shown in Figure 1.

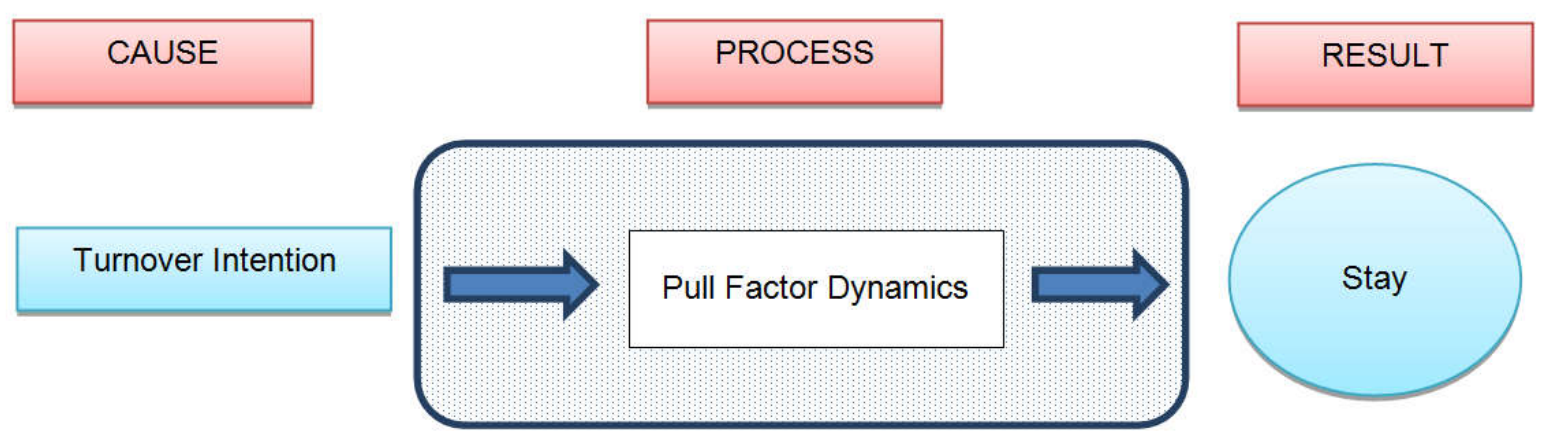

Figure 1 - Research Model Plan

\section{RESULTS AND DISCUSSION}

Individual Responsibilities. Supervisor is the first-line manager (middle manager) who needs to be responsible to the line member (operator). In working position, employee as personal tends to have creativity, imagination, spirit, and self-achievement. Employee shows the ability of self-control and initiative responsibility so that the operator will be more motivated. After the employee has turnover intention, the responsibility is still being carried out because the supervisor feels that the responsibility to line member is not only as work relationship but also as a sympathetic person. The form of responsibilities is: presence, finishing the assignments, not to talk back, and not to give bad examples to the line members.

Individual Competency. Competency can be defined as ability and characteristics of somebody, in form of knowledge, skill, and behavioral attitude needed for the implementation of job. A supervisor should have spirit, willing, and strong personality related in the field of work. A supervisor should believe that the competency in his field is acknowledged by other companies. By such self esteem, a supervisor can do the job well. If the competency is being acknowledged by the company, the employee will stay at the company.

The characteristics of employee's competency are having knowledge, capability, initiative and innovative attitude in every dimension of work: (1) Skill and attitude to solve the problem with orientation to efficiency, productivity, quality, and care to the environmental effect. (2) Skill and attitude in horizontal and vertical communication in building internal network.(3) Skill and attitude in self-emotional management, building friendship and perceptional objective.(4) Sustainable willing to study. (5) Skill and attitude on selfdevelopment related to the competency. (6) Skill and attitude of synergy between employees. The competencies that should be possessed by garment supervisor are: competency as a supervisor, understanding of sewing procedure, skill of clothing design, skill of cutting, skill of sewing, skill of finishing, and the knowledge of quality control. If a 
supervisor doesn't have those competencies the intention to leave the company will get stronger, because they are not feeling comfortable working for the garment company.

Individual Belief. A supervisor has a self-belief about the job he is working on. Belief is an attitude shown by people if he knows enough and concludes that he is reaching the truth. Because belief is an attitude, it is not always right and cannot be the guarantee of truth. Belief should always be tested and evaluated so that it will not lead to wrong attitude, action, or decision. Sometime, we are facing a situation which could not be easily decided, for example, the decision to move the town, to change the job, or to choose a work partner. But it should be remembered that we can choose emotion and certainly belief. Once the belief is set, it will focus on what could be done and what could happen. In growing positive belief, obstacles and deviations will occur as the part of a challenge. Employee's argument could be under estimated by the superiors and could also be rejected. But if there is a belief that the idea could lead to good advantages, the employee will hold on, stay strong and behave positively. Negative beliefs will slowly affect the intention to change. This may be the point where the failure to make a change occurs.

Praise for Individuals. Everyone is glad to be praised. The right words of praise will give working spirit and motivate the employees to do better job. Some simple words could motivate the employee in working, such as "you have done a great job and it fulfills my and company's expectation, "you are helpful and ease the load of my job» etc.

Bonus. Bonus is a good thing for an employee. However, it should be noted that too many expectations of bonus will lead to quick despair and lack of happiness. Therefore, leaders should inform the employees not to see the "amount" of bonus, but instead think that the bonus is a form of company's appreciation for their performance and productivity.

Individual Spirit. Working spirit is a condition that supports an employee to do the faster and better job at a company. This condition is an early depiction of one's productivity. It could be said that there is a tendency of direct relationship between high productivity and spirit. In bad condition of spirit, long-term productivity is hard to be achieved. Low spirit could decrease productivity. Lower profits can lead to fewer salary earnings in the future. A full and cumulative environment then occurs, because salary can affect the spirit. However, high spirits do not necessarily lead to high productivity; it is merely an influence even though it is important to the overall production. A workgroup can be happy as a result of the social relationship in work, but they may be so busy with themselves that their productivity is low. Employee's spirit is low in the absence of effective leadership. Because high spirit affects productivity profitably, it must be accompanied by management guidance and supervision.

Individual Training. Training is often regarded as the most visible and most common activity of all staffing activities. Superiors encourage training because through training the employees will become more skilled, and employees are expected to be more productive, but training time should also be taken into account. This calculation is important so that the training will not disturb on-going work. Training provided by the company, can generate the ability and confidence of employees who receive training. The training methods should be tailored to the conditions of employees and company. Human Resources training methods that are often used for the garment industry include on-the-job training method in which the employees learn through their work by observing other workers who are working, and then observe his behavior, and there is also Off the Job Training, which is to learn something outside his working hours. This is usually when there is a new model change that should be given to the supervisor and then the supervisor will train the line member (operator).

Good training and work ability can also support the success in a company in achieving its goals. Because these two factors will create a high level of work productivity and can support the success with the company. Conversely, if the level of work ability decreases, it will hinder the company in achieving its goals. The ability of employees within the organization is needed, to answer the competition with the company, where the changes in all fields occur very quickly, the development of increasingly complex and dynamic problems, and uncertain future in the life of society. Training as a motivational tool will encourage employees to work in optimum ability and to improve their performance. The training is 
intended to meet the work standards set by the company. From the above description, we can describe the pull factor model of individual turnover intention.
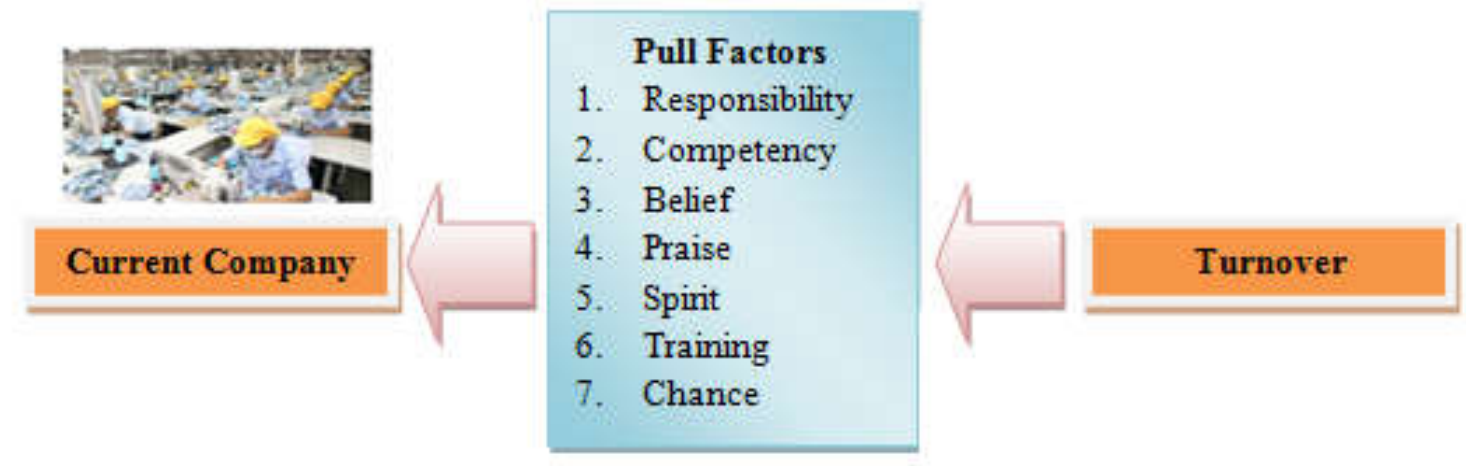

Figure 2 - Pull Factor of Individual Turnover Intention

The result of an individual pull factors is the factors become attractiveness to the employee, so that they will choose to stay and self controlled. Table 1 shows the research result about pull factors of employees to stay in the company.

Table 1 - Attractiveness Factors that Caused the Employees to Stay in the Company

\begin{tabular}{|c|c|}
\hline Adaptation & $\begin{array}{l}\text { From the above statement, stress at the workplace can be overcome with time and the level of } \\
\text { supervisor's adaptation when working. After the trial period, there is an award to the supervisor } \\
\text { in form of a certificate that causes the employee to stay and expect to get the certificate. } \\
\text { Employee who has an intention to quit is usually triggered by personal stress about making } \\
\text { mistakes or by difficulty to face members on the line. This stress can be contagious if not } \\
\text { properly controlled. } \\
\text { "At the time I worked, about the first up to the third month there was a change in work } \\
\text { patterns. The pattern changed because I needed to learn so many things about the new task» }\end{array}$ \\
\hline Motivation & $\begin{array}{l}\text { Attention, encouragement, and the understanding of behavior will make the employee more } \\
\text { willing to stay in the current company. Personal proximity and routines meet each other } \\
\text { causing close relationships among employees. Mutual support among employees can support } \\
\text { their work. } \\
\text { "Problems in the work will be solved if there is communication and mutual encouragement of } \\
\text { each other in all things, both in and outside the work, the aim is that the expected target can } \\
\text { be achieved» }\end{array}$ \\
\hline Locus of Control & $\begin{array}{l}\text { Supervisors in garment industry have internal locus of control, because they are confident that } \\
\text { the success and what is achieved today are because of their own efforts. They do not believe } \\
\text { that the fate caused them all. } \\
\text { "lf we want to be success we had to work hard, support from family and close persons is } \\
\text { important, but most of all it comes from within ourselves» }\end{array}$ \\
\hline $\begin{array}{c}\text { Work } \\
\text { Satisfaction }\end{array}$ & $\begin{array}{l}\text { Sometimes, employee joins the organization because of colleagues' invitation, and if the co- } \\
\text { workers leave the companies it will cause the invited employee want to follow the decision. If } \\
\text { the employee who invites stays at the company then the invited employee will also be at ease } \\
\text { and not willing to leave the company. } \\
\text { "My responsibility as a supervisor is not just for myself, but also to the company and to my line } \\
\text { members. Because the results of this work is not depend on me only, but depends on the } \\
\text { group (line members). If the results could be achieved then a sense of satisfaction will also be } \\
\text { achieved» }\end{array}$ \\
\hline Work Discipline & $\begin{array}{l}\text { Garment industry employees have work routines in working hours. The time is determined by } \\
\text { the company in order to achieve the goals of the organization. Discipline of working hours and } \\
\text { strict work methods caused the employees to only focus and think about the work and } \\
\text { achievement of targets set by the company. The meeting routine will affect each other. } \\
\text { "... Working in the garment industry requires high discipline because we as employees are } \\
\text { required to achieve the target that has been determined, if the line member is often absent } \\
\text { then the delay could occur and harm the company». }\end{array}$ \\
\hline Family Friendly & $\begin{array}{l}\text { Garment employees in Indonesia are predominantly female. Therefore, sociological and } \\
\text { stereotyped roles affect their view on the type of work and sex. Event facilities to support } \\
\text { togetherness also become an interesting place for them to comfort in work. } \\
\text { "We should be able to share the time between work and the family, I hope the company } \\
\text { continues to pay attention to our needs as women» }\end{array}$ \\
\hline
\end{tabular}




\section{CONCLUSION}

The cause of turnover intention of an individual perspective consists of successful implementation, responsibility, recognition, development, work itself and stress. Attitude is a response of like and dislike to objects. Job satisfaction is basically something that is personal. Each individual has a different level of satisfaction in accordance with the value system that applies to him. The higher the assessment of the perceived activity in accordance to the wishes of the individual is, the higher his satisfaction in the activity. Thus, satisfaction is an evaluation that describes a person for his feeling and attitude, such as happy or not happy, satisfied or dissatisfied in work. Satisfaction is because of an exciting job that full of challenges, and opportunities for achievement and promotion.

From the Individual side, an employee stays in the company because of responsibility, competence, confidence, praise, passion, training, and opportunities. Responsibility is a thing that is realized by the supervisor. The load on the line members is big enough so that if the achievement of the target has not been achieved it will cause the supervisor to survive. The supervisor's competencies that the company needs can be the supervisor's pull factor not to quit or moving jobs. Praise will cause the employee to feel satisfied and recognized by the leadership. Meanwhile, the spirit of survival can be obtained from the recognition of employees. Furthermore, training gives supervisors the opportunity to increase their ability to create new models. Finally, opportunities within the company to improve the position or career can still be achieved and will hold the supervisor in the company.

Employee has a choice after turnover intention to become a real turnover or not, even among the process. there is a process that causes the turnover does not occur directly or suddenly. This is because the intention can be strengthened or weakened not only from within the individual but also from external factors, such as: company policy or group work. This means that companies should be prepared to deal with these conditions by providing policies that can keep employees staying in the company. Maintaining employees needed to be done due to consideration of physical and psychological consequences of turnover. Based on the research result, the following suggestions are proposed: Company management and human-resource department should periodically conduct an evaluation or detection of turnover intention symptoms by working as a psychologist and/or human resources specialist. This is necessary so that the company can make early action plan if turnover intention becomes turnover. Future research may be possible to add time-control variables in the decision-making process that can lead to turnover intention of the employee/supervisor.

\section{REFERENCES}

1. Abbasi, S. M., Hollman, K. W., \& Hayes, R. D.(2008). Bad Bosses and How Not to Be One.Information Management Journal 42 (1): 52-56.

2. Alkahtani, A. H. (2015). Investigating Factors that Influence Employees' Turnover Intention: A Review of Existing Empirical Works. International Journal of Business and Management, 10(12), 152.

3. Bax, A. C. G. E. H. (2002). Lobour Turnover and its Effects on Performance: an Empirival Test Using Firm Data. The authors thank Germaine van Bree, Hans Ooteman and Raymond L. Schikhof for theirassistance in collecting the data and Peter van der Meer and Eric Molleman for their critical remarks on an earlier draft of this article.

4. Boswell, W. R., Boudreau, J. W., \&Tichy, J. (2005).The relationship between employee job change and job satisfaction: the honeymoon-hangover effect.Journal of applied psychology, 90(5), 882.

5. Chawla, D., \&Sondhi, N. (2011). Assessing the role of organizational and personal factors in predicting turn-over intentions: A case of school teachers and BPO employees. Decision, 38(2), 5.

6. Collins, C. J., \& Clark, K. D. (2003). Strategic human resource practices, top management team social networks, and firm performance: The role of human resource 
practices in creating organizational competitive advantage. Academy of management Journal, 46(6), 740-751.

7. Gudono. (2014). TeoriOrganisasi, Edisike 3, BPFE Yogyakarta, ISB:979-503-563-0.

8. Hatch, N. W., \& Dyer, J. H. (2004). Human capital and learning as a source of sustainable competitive advantage. Strategic management journal, 25(12), 1155-1178.

9. Iverson, R. D., \& Maguire, C. (2000). The relationship between job and life satisfaction: Evidence from a remote mining community. Human Relations, 53(6), 807-839.

10. Jha, S. (2012).Determinants of Employee Turnover Intentions: A Review.

11. Johnston, C. A., \&Naiman, R. J. (1990).Aquatic patch creation in relation to beaver population trends.Ecology, 1617-1621.

12. Kim, S. (2012). The impact of human resource management on state government IT employee turnover intentions.Public Personnel Management, 41(2), 257-279.

13. Krishnan, S. K., \& Singh, M. (2010). Outcomes of intention to quit of Indian IT professionals.Human Resource Management, 49(3), 421-437.

14. Lee T. W. \& Mitchell T. R. (1994).An Alternative Approach: The Unfolding Model of Voluntary Employee Turnover.Academy of Management Review, 19 (1): 51-89.

15. Lee, C. C., Huang, S. H., \& Zhao, C. Y. (2012).A study on factors affecting turnover intention of hotel empolyees.Asian Economic and Financial Review, 2(7), 866.

16. Maertz, C.P., \& Campion, M.A. 2004. Profiles in quitting: Integrating process and content turnover theory. Academy of Management Journal, 47, 566-582.

17. Mbah, S. E., \&lkemefuna, C. O. (2012).Job satisfaction and employees' turnover intentions in total Nigeria PLC in Lagos State.International Journal of Humanities and Social Science, 2(14), 275-287.

18. Holtom, B. C., Mitchell, T. R., Lee, T. W., \&Eberly, M. B. (2008).5 Turnover and Retention Research: A Glance at the Past, a Closer Review of the Present, and a Venture into the Future. Academy of Management annals, 2(1), 231-274.

19. Mobley, W. H. 1982. Intermediate Linkages in the Relationships between Job Satisfaction and Employee Turnover, Journal of Applied Psychology. 62(2): 237-240.

20. Mobley, W., Homer, S., \& Hollingsworth, A. 1978.An evaluation of precursors of hospital turnover.Journal of Applied Psychology, 63, 408-414.

21. Chandrashekaran, M., McNeilly, K., Russ, F. A., \&Marinova, D. (2000). From uncertain intentions to actual behavior: A threshold model of whether and when salespeople quit. Journal of Marketing Research, 37(4), 463-479.

22. PALUPI, D. A. P. (2011). Memprediksikan Turnover Pada Karyawan Perusahaan Garmen: Pengaruh Praktek Pengembangan Sumber Daya Manusiadan Kepercayaan Terhadap Organisasi. Jurnalllmu Manajemendan Akuntansi Terapan (JIMAT), 2(2).

23. Ertmer, P. A., \& Newby, T. J. (1993). Behaviorism, cognitivism, constructivism: Comparing critical features from an instructional design perspective. Performance improvement quarterly, 6(4), 50-72.

24. Price, J.L. (1992). A Handbook of Organizational Measurement.Lexington: D.C. Health.Psychological Contract Violation Develops. Academy of Management Review, 22, 226-256. Psychology, 52:122-126.

25. Blomme, R. J., Van Rheede, A., \& Tromp, D. M. (2010). The use of the psychological contract to explain turnover intentions in the hospitality industry: a research study on the impact of gender on the turnover intentions of highly educated employees. The International Journal of Human Resource Management, 21(1), 144-162.

26. Mowday, R. T., Koberg, C. S., \& McArthur, A. W. (1984). The psychology of the withdrawal process: A cross-validation test of Mobley's intermediate linkages model of turnover in two samples.Academy of management Journal, 27(1), 79-94.

27. Saeed, I., Waseem, M., Sikander, S., \&Rizwan, M. (2014).The relationship of Turnover intention with job satisfaction, job performance, Leader member exchange, Emotional intelligence and organizational commitment.International Journal of Learning \& Development, 4(2), 242-256. 
28. Sousa-Poza, A., \&Hennehenger, F. (2004).Analyzing Job Mobility with Job Turnover Intentions: An International Comparative Study.Journal of Economic Issue, 38(1), 113137.

29. Sugiyono. (2008). PendidikanPendekatanKuantitatif, Kualitatifdan R\&D. Bandung: Alfabeta.

30. Wike, D. H. (2014).PertumbuhanLemah, EksporTekstilTetapKuat.Diposting 24 Maret 2014.

31. Yin-Fah, B. C. 2010.An Exploratory Study on Turnover Intention among Private Sector Employees.International Journal of Business and Management, Vol. 5 (8): 57-64.

32. Yücel, I. (2012). Examining the Relationships among Job Satisfaction, Organizational Commitment, and Turnover Intention: An Empirical Study.International Journal of Business and Management, 7(20).

33. Zedeck, S. and Mosier, K. (1990). "Work in the family and employing organization". American Psychologist, 45, 240-251. 